\title{
"Now IS THE TIME TO ROOT OUT EVIL": The Role of Natural World Metaphors IN THE CONSTRUCTION OF THE "Us" AND "THEM" DiснотомY
}

\begin{abstract}
The paper focuses on metaphorical construction of the "Us" and "Them" groups in the discourse of U.S. President George W. Bush in the period ranging from 9/11 to May 2003. Three metaphorical motifs drawn from the source domain of natural world that contributed to the construction of the dichotomous representation are analysed: metaphors of "hunt", "plant" and "growth". The aim of the paper is to explore social and political impact of metaphors and their function in the process of creating the dichotomy. The theoretical framework that is adopted in the process of analysis draws on Critical Metaphor Analysis (CMA) proposed by Charteris-Black $(2004 a, 2005,2007,2014)$. This approach to metaphor analysis focuses on the interpretation of metaphors in their social context and on the exploration of ideology in texts. The findings from the analysis imply that "natural world" metaphors were employed as discursive devices that effectively conveyed arguments for the involvement of the USA in military operations in Afghanistan and Iraq.
\end{abstract}

Key words

Natural world metaphor; political speech; "us" and "them"; critical metaphor analysis; George W. Bush

\section{Introduction}

In the process of justification of overseas military operations after September 11, 2001, George W. Bush employed metaphorical language as an effective component 
in the creation of the dichotomy between "Us" (represented by the USA and its allies) and "Them" (terrorist networks and dictatorial regimes). This paper focuses on metaphorical construction of these dichotomous categories in political speeches of the speaker in the period ranging from September 11, 2001 to May 2003. In this period of time, the Bush administration attempted to discursively justify military operations in Afghanistan (October 2001) and in Iraq (March 2003). According to Musolff (1995: 95), the process of justification of military operations presents a "highly contentious issue, and metaphors and complete metaphorical scenarios have often been employed in attempts to vindicate the guilt of starting a war". Similarly, Chilton and Lakoff (1995: 56) suggest that metaphors "form the basis and the justification for the formulation of policy and its potential execution". After 9/11, the Bush administration adopted metaphorical projection into the "Us" and "Them" camps as a useful discursive strategy in the process of justification of the military operations overseas. For the purpose of the paper, metaphors drawn from the source domain of "natural world" (Cameron 2010, 2012) related to "hunt", "plant" and "growth" are presented as devices structuring the relationship between the two groups. The following set of metaphors related to more general NATURAL WORLD metaphor illustrates the relationship: THE USA IS A HUNTER, THE USA IS A GARDENER, TERRORISM/ TERRORIST ORGANIZATIONS ARE HARMFUL PLANTS, TERRORISTS ARE PARASITES and TERRORISM/ THE IRAQI REGIME IS A GROWING THREAT/ DANGER.

The aim of the paper is to explore social and political effects of these metaphors in the speaker's discourse and to observe how they function as persuasive rhetorical devices in the process of creating the polarization between the "Us" and "Them" groups. In order to investigate this aim, the following research questions have been formulated:

1. What is the role of "natural world" metaphors in the process of categorization into the "Us" and "Them" groups in George W. Bush's discourse after $9 / 11$ ?

2. What is metaphorical response of the USA towards the threat posed by terrorist organizations and dictatorial regimes?

The theoretical framework that is employed in the process of analysis of primary data is grounded in Critical Metaphor Analysis (CMA) proposed by CharterisBlack (2004a, 2005, 2007, 2014). CMA focuses on the analysis and interpretation of metaphors in their social context and on the investigation of "the intentions underlying language use" (Charteris-Black 2007: 45). According to CharterisBlack (2004a: 13) "critical analysis of metaphors can provide insight into the beliefs, attitudes and feelings of the discourse community in which they occur". Therefore, this framework presents an effective analytical tool in the process of revealing ideology that is present in texts.

George W. Bush's political speeches contributed to the formulation of a specific type of discourse which was based on the use of dichotomous oppositions. This 
type of discourse had global effects and it has introduced policy which shapes anti-terrorist activities of the USA at present. Therefore, the paper may have implications for the investigation of collective identities in the post-9/11 discourse.

George W. Bush's discursive practices after 9/11 have been discussed in Bhatia (2009), Cap (2014), (2016), (2017), Chilton (2004), Dunmire (2007), El-Hussari (2010), Ferrari (2007), Hodges (2011), Lazar and Lazar (2007), Oddo (2011). The studies also investigate the nature of terrorist threat and the represenatation of "Us" and "Them" in the speaker's discourse after 9/11.

As regards the use of metaphorical language in the period after 9/11, Zhang (2007: 31$)$ notes that "[s]ince September 11 terrorist attacks, the U.S. government has created a basket of influential metaphors to define its relations with its target world publics, to represent its position toward important international events, and to promote its key causes". Thus, in the period after $9 / 11$, metaphor provided an effective discursive device in the process of formulating the basic principles of U.S. foreign policy and also in the construction of the dichotomy between "Us" and "Them".

\section{The role of metaphor in constructing dichotomous representation ("us" vs. "them") in political discourse}

The dichotomy between "Us" and "Them" belongs to fundamental oppositions within the organization of human societies. In this dichotomous framework, "Our" group is seen as a basis for the unification and the "Them" group has qualities of distinct or antagonistic entity. Generally, the two groups "represent mutually exclusive categories" (Sandikcioglu 2000: 304). In the political realm, binary discourse is frequently employed in situations where there is a need to clearly distinguish between various oppositions, such as good vs. evil or right vs. wrong. When the separation between the two groups is established, there is an inherent inclination to portray "Us" as being more dominant than "Them". Leudar et al. (2004: 245) argue that "the two categories are a standardized relational pair - using one part of the pair [...] invokes the other". As a result, there are two entities or groups, which come into existence and they are marked by various forms of differences. Their separation is based on differences in "social, political and moral terms" (Leudar et al. 2004: 243) and it evokes rather simplified viewpoints which audiences generally prefer in situations where there is a need for polarization. Dichotomous frameworks also convey the image of an authority which is effective in the process of initiating actions against "Them".

Metaphor is considered an important discursive device which helps in understanding social and political processes (Lakoff and Johnson 1980; Perrez and Reuchamps 2015: 166). Political leaders can employ metaphors with the aim to reduce worldviews to various forms of binary oppositions. According to Charteris-Black (2005: 13) metaphor "influences the value that we place on ideas and beliefs on a scale of goodness and badness. It does this by transferring positive 
or negative associations of various source words to a metaphor target". Dichotomous polarization can be also achieved and reinforced with the use of metaphors which are "persuasive when combined with the semantic relation of contrast" (Charteris-Black 2005: 197; see also Boyd 2013: 300; Semino 2008: 91). Consequently, metaphors can be employed with the aim to support positive as well as negative associations with political groups, actors and also with particular ideologies. In this respect, Reisigl (2006: 599) suggests that metaphors contribute to positive presentation of "our-group" and also to "out - group segregation and discrimination (e.g. via deprecating animalizing metaphors like parasite, rat or vermin)". Therefore, metaphors can be strategically employed in situations when political actors intend to legitimise their actions and delegitimise their opponents or political and social groups. Legitimisation includes the acts associated with "positive self-presentation, [...] self-justification" and "self-identification as a source of authority" (Chilton 2004: 47) and it provides background for a possible justification of political goals. On the other hand, the acts of delegitimisation can be expressed by strategies that include, e.g., "attacking the rationality and sanity of the other" (Chilton 2004: 47). Therefore, delegitimisation contributes to negative categorization of specific social groups.

\section{Theoretical framework - Critical Metaphor Analysis (CMA)}

Theoretical framework that is adopted for the analysis of metaphors in George W. Bush's discourse is informed by Critical Metaphor Analysis (CMA) proposed by Charteris-Black (2004a, 2005, 2007, 2014). Charteris-Black (2004a: 42) suggests that "Critical Metaphor Analysis is a way of revealing underlying ideologies, attitudes and beliefs - and therefore constitutes a vital means of understanding more about the complex relationships between language, thought and social context". Critical Metaphor Analysis explores the function of metaphor which is related to the value system and ideological positions of societies and communities in which metaphors come into existence. This theoretical framework presents a useful extension of the approach associated with Critical Discourse Analysis (CDA). According to Charteris-Black (2004a: 27-28) "metaphor analysis should be a central component of critical discourse analysis" because metaphor is "concerned with forming a coherent view of reality". Charteris-Black (2014: 174) notes that the aim of Critical Metaphor Analysis is to "identify which metaphors are chosen in persuasive genres such as political speeches" (italics in original). Thus, the critical aspect of the analysis of metaphors lies in the recognition and description of metaphors that are used and also in the presentation of the motives of the speaker (s).

The framework integrates the cognitive approach and pragmatically-based approaches to metaphor analysis. According to Charteris-Black (2005), the analysis of metaphors should incorporate cognitive and pragmatic perspectives because metaphors can play an important role in the process of persuasion. The cognitive perspective is based on the assumption that metaphor plays an essential role in the 
conceptual structure and it is "caused by (and may cause) a shift in the conceptual system" (Charteris-Black 2004a: 21, italics in original; see also Lakoff and Johnson 1980). The pragmatic approach to analysis of metaphors involves the considerations related to the intentions and motivations of speakers in the process of production of metaphors. Therefore, metaphors are also seen as interpersonal resources that enable to enact the connection with receivers of discourse and consequently, they may have persuasive effects. This perspective on metaphor, which serves not only as a cognitive mechanism but also as a tool for shaping opinions and ideas is beneficial for the analysis of political discourse and the combination of the two approaches contributes to a comprehensive theory of metaphor.

CMA explores metaphorical concepts that are "employed systematically [...] to represent policies - such as war - as being in the interests of all" (Charteris-Black 2014: 174). Critical metaphor analysis focuses on the analysis of a speaker's objectives through the process of formulating research questions and defining the size of the corpus, singling out metaphors, the interpretation of metaphors and in the final stage, through the description and explanation of possible rationale through the interrelation with other metaphors. It also involves the consideration of "broader social and political context to determine the purposes that speakers had in using these metaphors" (Charteris-Black 2014: 176, Charteris-Black 2005).

\section{Data and methodology}

The corpus of political speeches for analysis consists of speeches delivered by George W. Bush in the period from September 2001 to May 2003. In this period of time, the speaker attempted to construct a dichotomous representation between "Us" and "Them" groups. The speaker's discursive effort to create this dichotomy provides a "shared discourse feature" (Charteris-Black 2014: 185) that is present across the corpus. It may be stated that the selected speeches constitute a representative sample of George W. Bush's rhetoric in the given period of time. The corpus of political speeches contains 92 political speeches and the total amount of data for the paper contains approximately 148,000 words. The transcripts of the speeches are available on the official website of the White House (georgewbushwhitehouse.archives.gov). The nature of the analysis in the paper is qualitative.

The political speeches delivered by the speaker were prepared in advance and the process of preparation involved "the organization and selection of each lexical item" (Wilson 1990: 60). This aspect contributed to an effective ideological impact of metaphorical language employed by the speaker. Forchtner (2013: 254) argues that political speeches present objectives "such as the creation of ingroup solidarity and/ or the construction of exclusionary (symbolic) boundaries". Therefore, political speeches have the potential for the creation of opposition between "Us" and "Them".

The method of analysis draws on Critical Metaphor Analysis proposed by Charteris-Black (2004a, 2005, 2007, 2014). The process of analysis involved four 
stages: the contextual analysis, identification of metaphors, interpretation and explanation of metaphors (Charteris-Black 2014). The first step involved "contextual analysis" of political speeches which required the formulation of the aims of the research, research questions concerning the investigation of metaphors in the discourse of the speaker and the description of the size of corpus. The second step was concerned with the identification of what could be considered "natural world" metaphor in the corpus of political speeches. The process involved the consideration of relevant words and important concepts. The third stage in the procedure included the classification of words from the source domain of "hunt", "plant", and "growth". At this stage, conceptual metaphors that illustrated the relationship between "Us" and "Them" were formed. The final stage of methodological procedure involved the explanation of the speaker's motivation with regards to the selection of metaphorical concepts and their contribution to the consolidation of ideological patterns.

\section{Analysis and discussion - natural world metaphors of "hunt", "plant" and "growth" in George W. Bush's discourse}

In this part of the paper, the focus will be placed on metaphors that convey dichotomous representation into the two opposing camps. Metaphorical concepts of "hunt", "plant" and "growth" evoke an offensive strategy that is to be adopted by the USA and they present an ideological vision of the world that involves the "neutralization" (Cap 2002: 73) of the enemies. In this process, the USA metaphorically assumes the position of an active hunter who searches for the prey and also "that of a gardener uprooting weeds and maintaining order" (Semino 2008: 78-79). Consequently, metaphors empower the USA to take an active action in the process of the confrontation of the enemies and at the same time, the scope of territorial action against "Them" can be broadened.

Cameron (2010: 602) notes that "the affective import" of "NATURAL WORLD" metaphors is largely negative in respect of terrorists" (see also Reisigl and Wodak 2001). The enemies in their roles of the "hunted animals", "harmful plants" and "growing threats and dangers" are metaphorically portrayed as aggressive, expanding and beyond the scope of control - as a result, they are legitimate targets for containment and elimination.

\subsection{The "hunt" metaphor - THE USA IS A HUNTER"}

The "hunt" metaphor - "with the aim of catching and/or killing" the enemies (Taylor 2002: 328) belongs to effective metaphorical concepts identified in George W. Bush's discourse. George W. Bush exploited this metaphor in his discourse consistently - it was employed for the first time on 9/11, in the first Bush's speech after the 9/11 attacks and in the later stages of the War on Terror discourse as well. The "hunt" metaphor corresponded to the general framework of U.S. 
foreign policy that was adopted after $9 / 11$ and that was based on the assumption that there was no negotiation with the enemies; similarly, the notion of "hunt" excludes any form of negotiation between the hunter and the hunted.

THE USA IS A HUNTER metaphor was employed as a response of the USA towards the acts of terrorism perpetrated by the enemies and it effectively captured the nature of the confrontation between "Us" and "Them". In the role of the "hunter", the USA "adopts a whole host of responsive actions against terrorism" (Hodges 2011: 46). The actions to counter terrorism may include e.g., intelligence gathering, strategic planning, special operations, long-term monitoring, tracking down, direct military confrontations, targeted killings, etc. As a result of the offensive efforts of the "hunter", the activity of enemies to operate is reduced and their ability to organise, coordinate and launch attacks is constantly disrupted. The "hunted" individuals are made to change their locations, which contributes to the reduction of their operational capabilities and to the "decimation of barbaric terrorism" (Bhatia 2008: 219).

With the help of the "hunt" metaphor, the speaker evokes the "war frame" (Hodges 2011:26-27) which is supported with the use of terms such as "coalition forces" (2), "military" (4), (7), "attacks" (6) or "enemies" (9). Lexical resources within the "war frame" that are used in reference to enemies include "murderers" (5), (7), "killers" (7), (9), (10) and "war criminals" (14). These references to "Them" contribute to the delimitation of the boundaries between "Us" and "Them" groups and are in opposition to "our" values and moral system.

Silberstein (2002: 5) notes that "[h]unting down and punishing could indicate covert actions, leading to, for example, assassination or bringing perpetrators to justice under U.S. or international law". The aspect of "bringing to justice" (and punishing as well) is presented in examples (1), (3), (5), (7), (8), (9), (10) and is associated with the general policy of the "hunt" for criminals. The use of the "hunt" metaphor conveys the intentions of the speaker as the process of "bringing to justice" necessarily involves an active action that has to be carried out against the enemies. Bringing to justice evokes the "crime frame" (Hodges 2011) and this idea serves as a powerful argument that creates the need for a military action and at the same time, it represents the capabilities of the USA in dealing with enemies. In this respect, Lazar and Lazar (2007: 52) observe that the USA presents itself as a "committed, thorough and effective global law enforcer". The appeal of the notion of "justice" also enables the USA to gain a wider support of the international community for the actions against "Them". The "hunt" metaphor is reflected in the following examples:

(1) The United States will hunt down and punish those responsible for these cowardly acts. (George W. Bush, Sept. 11, 2001)

(2) Afghanistan has been liberated; coalition forces continue to hunt down the Taliban and al-Qaeda. (George W. Bush, Sept. 14, 2001) 
(3) And as a nation of good folks, we're going to hunt them down, and we're going to find them, and we will bring them to justice. (George W. Bush, Sept. 25, 2001)

(4) I have called our military into action to hunt down the members of the al Qaeda organization who murdered innocent Americans. (George W. Bush, Nov. 8, 2001)

(5) We are deliberately and systematically hunting down these murderers, and we will bring them to justice. (George W. Bush, Nov. 8, 2001)

(6) Our great nation - national challenge is to hunt down the terrorists and strengthen our protection against future attacks. (George W. Bush, Nov. 8,2001$)$

(7) No matter how long it takes, no matter where we have to look, our United States military will patiently and surely hunt down the murderers and killers and terrorists, and bring them, one by one, to justice. (George W. Bush, Jan. 23, 2002)

(8) We're going to find them. We're going to slowly but surely hunt them down and bring them to justice. (George W. Bush, March 1, 2002)

(9) September the 11th was a day of great horror and great heroism. It was the first day of a long struggle against determined enemies. It was the first day in which this mighty nation will hunt down the killers and their like one by one and bring them to justice. (George W. Bush, May $15,2002)$

(10) I'm going to talk about homeland security, but the best way to secure our homeland is to hunt the killers down one by one and bring them to justice, and that is what we're going to do. (George W. Bush, Sept. 5, 2002)

(11) And we are hunting them down, the other day, one of them popped up, popped his head up, named bin al - Shibh. (George W. Bush, Oct. 4, 2002)

(12) We're hunting the terrorists on every continent. (George W. Bush, Jan. 3, 2003)

(13) Across the world, we are hunting down the killers one by one. (George W. Bush, Feb. 26, 2003) 
(14) Given the nature of this regime, we expect such war crimes, but we will not excuse them. War criminals will be hunted relentlessly and judged severely. (George W. Bush, Mar. 28, 2003)

Successful outcomes of the hunt for terrorists are presented in (11). In this example, George W. Bush refers to the capture of "one of them" which indicates progress in the war on terror. It also implies the effectiveness of implemented military or intelligence measures and the commitment of the USA to continue the "hunt" for terrorists. Territorial aspects of the hunt are illustrated in examples (12) and (13) - they demonstrate the flexibility of the USA in the process of "chasing" the enemies in other parts of the world. Thus, the territorial scope of the action against "Them" is extended. This observation is reflected in the resolve of the USA to participate in worldwide military campaigns and it also serves as a demonstration of the power of the hunter.

With the help of the "hunt" metaphor, the enemies are also deprived of human features; they are dehumanized (Chovanec 2010). Dehumanization implies "the denial of [...] placement within some group constituted by humans" (Chovanec 2010: 69). Dehumanized enemies do not act in accordance with the rules of civilization and have tendencies to behave in a violent way; they are "outside of the dominion of human society, and can be hunted" (Santa Ana 1999: 202). By presenting the actions of the USA (and of the allies that take the role of the "hunters" as well) in terms of the "hunt" metaphor within which the enemies are conceptualized as dehumanized entities, the speaker constructs the identity of the enemy that is threatening, dangerous and beyond the scope of control.

In a larger framework, the "hunt" metaphor presents various types of dichotomies, such as civilization vs. savagery, the rule of law vs. disorder or rational vs. irrational. Given this fact, the response of the United States should incorporate the aspect of the "hunt" as a strategy that involves the use of harsh power. This ideological position could be reinforced if it is presented in terms of a physical struggle between the two sides. The idea of struggle (between the "hunter" and the "hunted") suggests that it is an active action in which two groups participate and a certain amount of effort is spent (Ferrari 2007). In general, the aspect of the "hunt" metaphor is a part of a larger rhetorical construction of the threat posed by the enemies.

\subsection{The "plant" metaphor - THE USA IS A GARDENER, TERRORISM/ TERRORIST ORGANIZATIONS ARE HARMFUL PLANTS, TERRORISTS ARE PARASITES}

Ritchie (2013: 78) observes that gardening belongs to "primary metaphors based on culture-specific experiences" and in his discourse, George W. Bush employed metaphorical concepts related to "gardening", "plants" and "parasites" that enabled to construct the confrontation between "Us" and "Them". In the role of the 
"gardener", the USA opposes the enemy forces by an active process of removing and "rooting out" and is also involved in the elimination of hostile elements that are presented as parasites. THE USA IS A GARDENER metaphor refers to the efforts of the USA to reduce the potential of enemies to operate as complex organizations. The metaphor also conveys the image of "cultivation" that is necessary in order to prevent the development of terrorism and terrorist organizations which are metaphorized as harmful plants and parasites. Metaphorically, the process of cultivation improves the structure and organization of societies as it prevents the increase in terrorist activity. The cultivation requires an intervention of an agent whose role is to manage the "garden" with a variety of techniques. The action also includes direct military operations which result into the subsequent enforcement of control in the territories. The outcome of this process contributes to an increased resistance of societies to terrorism.

Metaphors drawn from the source domain of e.g., plants can be used in the process of persuasion (Charteris-Black 2004b: 145). The "plant" metaphor has a "powerful rhetorical role in providing an evaluation; it is very rare for any plant metaphor not to convey a very important covert evaluation of positive or negative forms of behaviour" (Charteris-Black 2004a: 195-196; see also Charteris-Black 2004b: 146). In George W. Bush's discourse, positive aspects of the "plant" metaphor are associated with the figure of "gardener" that is responsible for counter - terrorism actions, reduction of terrorist activities and conditions that enable the development of terrorist organizations. On the other hand, the evaluation of the activities of the enemies is conceptualised in a negative way with the purpose of their demonization and pointing to negative increase of their power. This aspect can be achieved with metaphor TERRORISM/ TERRORIST ORGANIZATIONS ARE HARMFUL PLANTS.

The "plant" metaphor is classified within "living organism" metaphors which can be extended to societies as well (Kövecses 2004: 105). Kövecses (2010: 10) provides the following "set of mappings" which are also used in metaphorical motifs exploited in George W. Bush's discourse. In this case, "target" refers to social organizations that take the form of terrorist networks or terrorism.

Source: PLANT

(a) the whole plant

(b) a part of the plant

(c) growth of the plant

(d) removing a part of the plant

(e) the root of the plant

(f) flowering

(g) the fruits of the crops $\rightarrow$ Target: SOCIAL ORGANIZATION

$\rightarrow$ the entire organization

$\rightarrow$ a part of the organization

$\rightarrow$ development of the organization

$\rightarrow$ reducing the organization

$\rightarrow$ the origin of the organization

$\rightarrow$ the best stage, the most successful stage

$\rightarrow$ the beneficial consequences

(Kövecses 2010: 10)

Terrorism and terrorist organizations are conceptualised as complex structures (i.e. plants) with their own system of functioning and gradual development. The growth 
of plants from roots is seen as a natural process, which can be realized through a coordinated series of actions such as absorbing nutrients from the soil, distribution of water through the structures of a plant, etc. This conveys the image of terrorist organizations that gradually develop and reinforce their presence in the world.

In order to prevent the possible "flowering" of harmful plants presented as terrorist organizations, it is essential to reduce their development and integrity as they may become dangerous units. This gives an active agency to the USA which is supposed to "weed out" and cultivate the respective areas of the world. This action involves dismantling logistics networks, infrastructure and also direct confrontations with the enemies. Consequently, the ability of terrorist organizations to operate as complex entities could be weakened. George W. Bush formulated the "plant" metaphor in the following examples:

(15) We are planning a broad and sustained campaign to secure our country and eradicate the evil of terrorism. (George W. Bush, Sept. 15, 2001)

(16) But the only way to defeat terrorism as a threat to our way of life is to stop it, eliminate it, and destroy it where it grows. (George W. Bush, Sept. 20, 2001)

(17) And I don't care how long it takes to root out terrorism, we're going to do it. (George W. Bush, Sept. 25, 2001)

(18) Now is the time - now is the time to root out evil so that our children can live with freedom as the beacon all around the world. (George W. Bush, Oct. 4, 2001)

(19) We are paving the way for friendly troops to defeat the Taliban and root out the al Qaeda parasites that the Taliban hosts and protects. (George W. Bush, Oct. 17, 2001)

(20) And some governments, while pledging to uphold the principles of the U.N., have cast their lot with the terrorists. They support them and harbor them, and they will find that their welcome guests are parasites that will weaken them, and eventually consume them. (George W. Bush, Nov. 10, 2001)

(21) My hope is that all nations will heed our call, and eliminate the terrorist parasites who threaten their countries and our own. Many nations are acting forcefully. (George W. Bush, Jan. 29, 2002)

(22) America encourages and expects governments everywhere to help remove the terrorist parasites that threaten their own countries and peace of the world. (George W. Bush, March 11, 2002) 
(23) Poverty doesn't create terror - yet terror takes root in failing nations that cannot police themselves or provide for other people. (George W. Bush, May 23, 2002)

The "plant" metaphor indicates that "strong counter actions are needed to prevent natural growth" (Cameron 2010: 602). In examples (15-19), (21-22), the USA is metaphorically presented in the role of the "gardener" whose task is to "eliminate" (16), "destroy" (16) or "root out" (17-19) the "origins of the organization" (Kövecses 2010: 10) and expanding elements that are associated with "Them". The origins of the organizations represented in the form of roots are important sources of activity as they activate the growth of harmful plants, i.e. terrorist organizations. Roots provide resources for the stabilization and further consolidation of the activity of plants that are depicted as terrorist structures; therefore, their development has to be prevented or completely "eliminated", "rooted out" or "eradicated". This process also includes the confrontation with resilient elements that form the root itself - these elements may represent leaders who provide direction for terrorist organizations, core members and command structures of terrorist groups. In the process, roots have also to be separated from the rest of plants and the purpose of "rooting out" is to prevent terrorist organizations from proliferation as the roots may re-sprout and subsequently grow new plants. The elimination in the form of "rooting out" also involves penetration into underground which is associated with the image of darkness (see Charteris-Black 2005, 2014).

Cameron (2010: 601) suggests that "terrorism requires a nourishing medium in which to grow". This aspect is presented in (23) in which George W. Bush refers to the conditions that enable terror to take roots in "failing nations". An optimal environment for terrorism can be created by e.g., poor socio-economic conditions, political instability, high level of corruption or by direct help provided by state sponsors of terrorism. These factors can subsequently establish favourable conditions for possible development of terrorist organizations and for terrorist activities. On the basis of this situation, the USA is supposed to prevent the seeds of terrorism from taking their roots.

George W. Bush in his discourse refers to terrorists as "parasites", thus giving rise to the TERRORISTS ARE PARASITES metaphor. The notion of "parasite" in discourse is discussed in Musolff (2010, 2014, 2015, 2016, 2017). According to Musolff (2016: 73), the classification of various social groups as parasites illustrates a "prototypical example of semantic mapping from the biological to the social domain". In examples (20) and (22), the "parasite" metaphor evokes the image of a parasitic plant that acquires nutrients from other plants. Parasites are able to penetrate to various locations and they can then proceed to healthy parts of the host's structures. In the process, the host may be harmed or seriously weakened. This image evokes the infiltration of terrorists into the system of other states as well as a gradual establishment of terrorist sanctuaries. Given this situation, the USA has to prevent the penetration of "terrorist parasites" into the areas that are considered important. 
In the speaker's discourse, parasites are depicted in the state of activity - they are able to "threaten" (21), (22) or "consume" (20) societies. Thus, parasites significantly affect societies that host them. Musolff (2016: 91) notes that this metaphor "suggests the existence of a deadly threat which must be countered by the most radical measures, that is, elimination of the parasite" (see also CharterisBlack 2005: 182; Musolff 2010: 36, Musolff 2017). In order to remove and "root out" parasites, an active action as well as "social and political counter-measures" (Musolff 2015: 50) are required. This indicates an active involvement of the USA in military campaigns overseas and the development of defensive measures in order to prevent the penetration of parasites into "our" society.

In (19), the Taliban regime is portrayed as an entity that hosts and supports the existence of terrorists metaphorized as "parasites" that may later spread and operate in other parts of the world. Terrorists can benefit from various resources provided by their hosts in the form of e.g., shelter, supplies, training facilities, or weapons. As a result, they may be able to extend the scope of their actions, which has considerable impacts on global security.

\subsection{The "growth" metaphor-TERRORISM/THE IRAQI REGIME IS A GROWING THREAT/ DANGER}

\section{TERRORISM/ THE IRAQI REGIME IS A GROWING THREAT/ DANGER} metaphor was exploited in the period before military operation in Iraq in 2003, and it primarily referred to the increasing threats and dangers posed by terrorist groups and the Iraqi regime. Growing "threats and dangers" can be seen as effective tools for the representation of enemy which served in the description of the "other" that threatened "Us".

The power of this metaphor lies in the fact that the threats and dangers posed by the terrorist groups and the Iraqi regime have the properties of living organisms. Therefore, the increasing size of "threats and dangers" poses negative consequences for the countries and territories where they grow. Given the fact that growth is a natural feature of living organisms, "growing threats and dangers" metaphorized in the form of terrorism and dictatorial regimes should not be allowed to develop and penetrate into "our" areas and territories. From the perspective of the USA, "growing threats and dangers" had to be prevented from expanding; they had to be either completely eliminated, or contained to the greatest possible degree. Growing threats and dangers are "uncontrollable in analogy to natural forces" (Sandikcioglu 2000: 316) and they reflect the preoccupation of the USA with enemies. The speaker formulated the "growth" metaphor in the following examples:

(24) At the same time, the civilized world must take seriously the growing threat of terror on a catastrophic scale. We've got to prevent the spread of weapons of mass destruction, because there is no margin for error... (George W. Bush, March 15, 2002) 
(25) Congress must make it unmistakably clear that when it comes to confronting the growing danger posed by Iraq's efforts to develop or acquire weapons of mass destruction, the status quo is totally unacceptable. (George W. Bush, Sept. 14, 2002)

(26) The danger to America from the Iraqi regime is grave and growing. (George W. Bush, Oct. 5, 2002)

(27) The Iraqi regime is a serious and growing threat to peace. (George W. Bush, Oct. 16, 2002)

(28) The threats to the homeland are growing threats. These people aren't going away any time soon. And so the need for action is important. (George W. Bush, Nov. 12, 2002)

(29) The safety of the American people depends on ending this direct and growing threat. (George W. Bush, Feb. 26, 2003)

(30) And for the government of the United States and the coalition we lead, there is no doubt: we will confront a growing danger, to protect ourselves, to remove a patron and protector of terror, and to keep the peace of the world. (George W. Bush, Mar. 15, 2003)

In political discourse, the aspects of "growing" or "flourishing" are evaluated positively, especially in relation to economic issues (e.g., "the growth of economy"; see Charteris-Black 2004b; Chilton 1996: 184; Chow, 2014; Goatly 2007: 28-29; Kövecses 2010: 25; White 2003). However, in the examples above the speaker presents growing terrorist threats and dangers in a different way - as potentially harmful elements whose spread needs to be controlled or stopped. Metaphorical motifs employed by the speaker in examples (25), (29), (30) call for an offensive strategy against expansive and advancing elements that threaten e.g., American society, as the speaker declares in (26) and (28). The "growth" metaphor places the USA into the role of the "destroyer" of the terrorist threat and it gives power to actively confront "threatening outsiders" (Semino 2008: 78; see also Bhatia 2015; Cap 2014: 23-24). This conveys the image of defensive as well as offensive activities of the USA against the enemies.

According to Chilton (1996: 184), the entity that is growing "seeks to influence others" and it "acts aggressively". The imagery of an aggressive growth could be reinforced by its motion as the invasive entities may flourish to cultivated areas. Therefore, for the purposes of self-defence against invasive elements from the outside, it is important to contain threats and dangers approaching "our" areas. The image of gradual growth and penetration may contribute to the evocation of fear (Bhatia 2008; Cap 2016; Chilton 2004; Ferrari 2007; O’Brien 2003). 


\section{Conclusion}

Musolff (2004: 2) observes that "politics, as part of the social domain, must also be perceived and constructed metaphorically". Therefore, metaphorical language and rhetoric may be effective in the process of asserting certain political attitudes and they can be used in order to introduce and "stabilize ideological frameworks" (Skinner and Squillacote 2010: 45). At the same time, metaphors create a certain basis for the articulation and justification of a particular type of policy and its possible realization. They are figures of speech which can be widely exploited in political discourse because they contribute to the construction of "a shared system of belief" (Charteris-Black 2005: 20).

The aim of the paper has been to explore the discursive properties of George W. Bush's speeches that contributed to the construction of the dichotomous representation between "Us" and "Them". The discussion in the paper has tended to focus on metaphors employed by the speaker within the larger framework of the post-9/11 discourse in which metaphor elaborated an ideological force and was used to present metaphorical categorisation into the two camps.

The use of metaphors in George W. Bush's discourse corresponds to the observation that they "should reflect the primary discourse function of providing social direction and leadership" (Charteris-Black 2005: 87). In the speaker's discourse, metaphorical sources for the creation of opposition between "our group" and "their group" also included metaphors drawn from the source domain of natural world - metaphorical concepts of "hunt", "plant" and "growth" evoked an inherently confrontational character of the clash between "Us" and "Them" and they positioned the USA into the role of the destroyer of the threat posed by the enemies. These concepts presented the efforts and resolution of the USA to remove the terrorist threat, they attributed an active agency to the USA and extended the area of action against "Them". At the same time, the "Them" group was metaphorically portrayed as dehumanized and expanding. As a result, the two camps were involved in a direct struggle which involved confrontation.

\section{Note}

In the analysis, conceptual metaphors are presented in small capital letters and relevant passages from the speaker's discourse are in bold.

\section{References}

Bhatia, Aditi (2008) Discursive illusions in the American National Strategy for Combating Terrorism. Journal of Language and Politics 7(2), 201-227. doi: 10.1075/jlp.7.2.02bha

Bhatia, Aditi (2009) The discourses of terrorism. Journal of Pragmatics 41(2), 279-289. doi: 10.1016/j.pragma.2008.05.016

Bhatia, Aditi (2015) Discursive Illusions in Public Discourse: Theory and Practice. Oxon: Routledge. 
Boyd, Michael S. (2013) Reframing the American Dream: Conceptual metaphor and personal pronouns in the 2008 US presidential debates. In: Okulska Urszula, Piotr Cap (eds.) Analyzing Genres in Political Communication. Amsterdam and Philadelphia: John Benjamins, 297-319.

Cameron, Lynne (2010) Responding to the risk of terrorism: The contribution of metaphor. D.E.L.T.A. 26 (special issue), 587-614. doi: 10.1590/S0102-44502010000300010

Cameron, Lynne (2012) Comparing responses to violence and uncertainty in Brazil and the UK: A collaborative project. ANTARES 4(7), 8-28.

Cap, Piotr (2002) Explorations in Political Discourse: Methodological and Critical Perspectives. Frankfurt am Main: Peter Lang.

Cap, Piotr (2014) Applying cognitive pragmatics to critical discourse studies: A proximization analysis of three public space discourses. Journal of Pragmatics 70, 16-30. doi: 10.1016/j.pragma.2014.05.008

Cap, Piotr (2016) The Language of Fear: Communicating Threat in Public Discourse. London: Palgrave Macmillan.

Cap, Piotr (2017) Studying ideological worldviews in political discourse space: Critical-cognitive advances in the analysis of conflict and coercion. Journal of Pragmatics 108, 17-27. doi: 10.1016/j.pragma.2016.11.008

Charteris-Black, Jonathan (2004a) Corpus Approaches to Critical Metaphor Analysis. Basingstoke: Palgrave Macmillan.

Charteris-Black, Jonathan (2004b) Why an angel rides in the whirlwind and directs the storm: A corpus- based comparative study of metaphor in British and American political discourse. In: Advances in corpus linguistics: Papers from the 23rd International Conference on English Language Research on Computerized Corpora (ICAME 23). New York and Amsterdam: Rodopi, $133-150$.

Charteris-Black, Jonathan (2005) Politicians and Rhetoric: The Persuasive Power of Metaphor. New York: Palgrave Macmillan.

Charteris-Black, Jonathan (2007) The Communication of Leadership: The Design of Leadership Style. Oxon: Routledge.

Charteris-Black, Jonathan (2014) Analysing Political Speeches: Rhetoric, Discourse and Metaphor. New York: Palgrave Macmillan.

Chilton, Paul (1996) Security Metaphors: Cold War Discourse from Containment to Common House. New York: Peter Lang Publishing.

Chilton, Paul (2004) Analysing Political Discourse: Theory and Practice. London: Routledge.

Chilton, Paul and George Lakoff (1995) Foreign policy by metaphor. In: Schäffner, Christina and Anita L. Wenden (eds.) Language and Peace. Aldershot: Ashgate, 37-60.

Chovanec, Jan (2010) Legitimation through differentiation. In: Okulska, Urszula and Piotr Cap (eds.) Perspectives in Politics and Discourse. Amsterdam: John Benjamins, 61-81.

Chow, Mei Yung Vanliza (2014) The movements of the economy: Conceptualizing the economy via bodily movement metaphors. Metaphor and the Social World (4)1, 3-26. doi: 10.1075/ msw.4.1.01cho

Dunmire, Patricia L. (2007) "Emerging threats" and "coming dangers": Claiming the future for preventive war. In: Hodges, Adam and Chad Nilep (eds.) Discourse, War and Terrorism. Amsterdam: John Benjamins, 19-43.

El-Hussari, Ibrahim A. (2010) President Bush's address to the nation on U.S. policy in Iraq: A critical discourse analysis approach. In: Okulska, Urszula and Piotr Cap (eds.) Perspectives in Politics and Discourse. Amsterdam: John Benjamins, 99-118.

Ferrari, Federica (2007) Metaphor at work in the analysis of political discourse: Investigating a "preventive war" persuasion strategy. Discourse and Society 18(5), 603-625. doi: $10.1177 / 0957926507079737$

Forchtner, Bernard (2013) Legitimizing the Iraq War through the genre of political speeches: Rhetorics of judge-penitence in the narrative reconstruction of Denmark's cooperation with Nazism. 
In: Cap, Piotr and Urszula Okulska (eds.) Analyzing Genres in Political Communication. Amsterdam and Philadelphia: John Benjamins, 239-265.

Goatly, Andrew (2007) Washing the Brain - Metaphor and Hidden Ideology. Amsterdam/ Philadelphia: John Benjamins.

Hodges, Adam (2011) The "War on Terror" Narrative: Discourse and Intertextuality in the Construction and Contestation of Sociopolitical Reality. New York: Oxford University Press.

Kövecses, Zoltán (2004) Metaphor and Emotion: Language, Culture, and Body in Human Feeling. Cambridge: Cambridge University Press.

Kövecses, Zoltán (2010) Metaphor: A Practical Introduction (2nd edn.). Oxford: Oxford University Press.

Lakoff, George and Mark Johnson (1980) Metaphors We Live By. Chicago: University of Chicago.

Lazar, Annita and Michelle M. Lazar (2007) Enforcing justice, justifying force. America's justification of violence in the new world order. In: Hodges, Adam and Chad Nilep (eds.) Discourse, War and Terrorism. Amsterdam: John Benjamins, 45-65.

Leudar, Ivan, Victoria Marsland and Jiři Nekvapil (2004) On membership categorization: "Us", "them" and "doing violence" in political discourse. Discourse and Society 15(2-3), 243-266. doi: $10.1177 / 0957926504041019$

Musolff, Andreas (1995) Promising to end a war = language of peace? The rhetoric of allied news management in the Gulf War 1991. In: Schäffner, Christina and Anita L. Wenden (eds.) Language and Peace. Aldershot: Ashgate, 93-110.

Musolff, Andreas (2004) Metaphor and Political Discourse: Analogical Reasoning in Debates about Europe. New York: Palgrave Macmillan.

Musolff, Andreas (2010) Political metaphor and bodies politic. In: Okulska, Urszula and Piotr Cap (eds.) Perspectives in Politics and Discourse. Amsterdam: John Benjamins, 23-41.

Musolff, Andreas (2014) Metaphorical parasites and "parasitic" metaphors: Semantic exchanges between political and scientific vocabularies. Journal of Language and Politics 13(2), 218-233. doi: 10.1075/jlp.13.2.02mus

Musolff, Andreas (2015) Dehumanizing metaphors in UK immigrant debates in press and online media. Journal of Language Aggression and Conflict 3(1), 41-56. doi: 10.1075/jlac.3.1.02mus

Musolff, Andreas (2016) Political Metaphor Analysis: Discourse and Scenarios. London: Bloomsbury Academic.

Musolff, Andreas (2017) Metaphor and persuasion in politics. In: Semino, Elena and Zsófia Demjén (eds.) The Routledge Handbook of Metaphor and Language. Oxon: Routledge, 309-322.

O'Brien, Gerald V. (2003) Indigestible food, conquering hordes, and waste materials: Metaphors of immigrants and early immigration restriction in the United States. Metaphor and Symbol 18(1), 33-47. doi: 10.1207/S15327868MS1801_3

Oddo, John (2011) War legitimation discourse: Representing "us" and "them" in four US presidential addresses. Discourse and Society 22(3), 287-314. doi: 10.1177/0957926510395442

Perrez, Julien and Min Reuchamps (2015) Special issue on the political impact of metaphors. Metaphor and the Social World, 5(2), 165-176. doi: 10.1075/msw.5.2

Reisigl, Martin (2006) Rhetorical tropes in political discourse. In: Keith Brown (ed.) Encyclopaedia of Language and Linguistics, second edition. Boston: Elsevier Publishing, 596-603.

Reisigl, Martin and Ruth Wodak (2001) Discourse and Discrimination: Rhetorics of Racism and Antisemitism. London: Routledge.

Ritchie, David L. (2013) Metaphor. Cambridge: Cambridge University Press.

Sandikcioglu, Esra (2000) More metaphorical warfare in the Gulf: Orientalist frames in news coverage. In: Antonio Barcelona (ed.) Metaphor and Metonymy at the Crossroads: A Cognitive Perspective. Berlin: Mouton de Gruyter, 299-320.

Santa Ana, Otto (1999) "Like an animal I was treated": Anti-immigrant metaphor in US public discourse. Discourse and Society 10(2), 191-224. doi: 10.1177/0957926599010002004

Semino, Elena (2008) Metaphor in Discourse. Cambridge: Cambridge University Press. 
Silberstein, Sandra (2002) War of Words: Language, Politics and 9/11. London: Routledge.

Skinner, Daniel and Rosa Squillacote (2010) New bodies: Beyond illness, dirt, vermin, and other metaphors of terror. In: Okulska, Urszula and Piotr Cap (eds.) Perspectives in Politics and Discourse. Amsterdam: John Benjamins, 43-60.

Taylor, John R. (2002) Category extension by metonymy and metaphor. In: Dirven, René and Ralf Pörings (eds.) Metaphor and Metonymy in Comparison and Contrast. New York: Mouton de Gruyter, 323-347.

White, Michael (2003) Metaphor and economics: The case of growth. English for Specific Purposes 22(2), 131-151. doi: 10.1016/S0889-4906(02)00006-6

Wilson, John (1990) Politically Speaking: The Pragmatic Analysis of Political Language. Oxford: Basil Blackwell.

Zhang, Juyan (2007) Beyond anti-terrorism: Metaphors as message strategy of post September-11 U.S. public diplomacy. Public Relations Review 33(1), 31-39. doi: 10.1016/j.pubrev.2006.11.006

MareK Hampl is an assistant lecturer at Department of English Language and Literature, University of Žilina in Žilina, Slovakia. His research interests include analysis of political discourse with the focus on the representation of the "Us" and "Them" groups in political speeches and on the area which is related to the doctrines of American foreign policy in the Cold War period.

Address: Mgr. Marek Hampl, Ph.D., Department of English Language and Literature, Faculty of Humanities, University of Žilina, Univerzitná 8215/1, 01026 Žilina, Slovak Republic. [e-mail: marek.hampl@fhv.uniza.sk] 